\title{
Role of the gap junctions in the contractile response to agonists in pulmonary artery from two rat models of pulmonary hypertension
}

\author{
Marie Billaud ${ }^{1,2 \dagger}$, Diana Dahan ${ }^{1,2+}$, Roger Marthan ${ }^{1,2,3}$, Jean-Pierre Savineau ${ }^{1,2}$, Christelle Guibert ${ }^{1,2^{*}}$
}

Background: Pulmonary hypertension $(\mathrm{PH})$ is characterized by arterial vascular remodelling and alteration in vascular reactivity. Since gap junctions are formed with proteins named connexins $(C X)$ and contribute to vasoreactivity, we investigated both expression and role of $C x$ in the pulmonary arterial vasoreactivity in two rat models of PH.

Methods: Intrapulmonary arteries (IPA) were isolated from normoxic rats $(\mathrm{N})$, rats exposed to chronic hypoxia (CH) or treated with monocrotaline (MCT). RT-PCR, Western Blot and immunofluorescent labelling were used to study the Cx expression. The role of $\mathrm{Cx}$ in arterial reactivity was assessed by using isometric contraction and specific gap junction blockers. Contractile responses were induced by agonists already known to be involved in $\mathrm{PH}$, namely serotonin, endothelin-1 and phenylephrine.

Results: Cx 37, 40 and 43 were expressed in all rat models and $\mathrm{Cx} 43$ was increased in $\mathrm{CH}$ rats. In IPA from N rats only, the contraction to serotonin was decreased after treatment with ${ }^{37-43} \mathrm{Gap} 27$, a specific $\mathrm{Cx}$-mimetic peptide blocker of Cx 37 and 43 . The contraction to endothelin-1 was unchanged after incubation with ${ }^{40} \mathrm{Gap} 27$ (a specific blocker of $\mathrm{Cx} 40$ ) or ${ }^{37-43} \mathrm{Gap} 27$ in N, CH and MCT rats. In contrast, the contraction to phenylephrine was decreased by ${ }^{40} \mathrm{Gap} 27$ or ${ }^{37-43} \mathrm{Gap} 27$ in $\mathrm{CH}$ and MCT rats. Moreover, the contractile sensitivity to high potassium solutions was increased in $\mathrm{CH}$ rats and this hypersensitivity was reversed following ${ }^{37-43} \mathrm{Gap} 27$ incubation.

Conclusion: Altogether, Cx 37, 40 and 43 are differently expressed and involved in the vasoreactivity to various stimuli in IPA from different rat models. These data may help to understand alterations of pulmonary arterial reactivity observed in $\mathrm{PH}$ and to improve the development of innovative therapies according to $\mathrm{PH}$ aetiology.

\section{Background}

Gap junctions are clusters of intercellular channels resulting from the connection of two hexameric assembly of membrane proteins termed connexins $(\mathrm{Cx})$ [1]. Each hexameric assembly is also known as a hemichannel or connexon, localized on the membrane of two adjacent cells and arranged with identical Cx (homomeric connexon) or different Cx (heteromeric connexon) with various possible combinations [2]. Such process has functional consequences and provides an efficient cellular strategy to finely regulate cell-to-cell communication. In the vascular wall, the most common

\footnotetext{
* Correspondence: christelle.guibert@u-bordeaux2.fr

† Contributed equally

'INSERM, U1045, 146 rue Léo Saignat, F-33076 Bordeaux, France

Full list of author information is available at the end of the article
}

connexins are $\mathrm{Cx} 37, \mathrm{Cx} 40$ and $\mathrm{Cx} 43$ in endothelial and smooth muscle cells [3]. Gap junctions allow cell-to-cell coupling in between vascular cells of the same type, namely endothelial or smooth muscle cells but they are also present in between endothelial and smooth muscle cells (myoendothelial gap junctions). Gap junctions allow direct diffusion of ions and small molecules between adjacent cells in almost all animal tissues. As a consequence, gap junctions are vital components in the coordination of vascular response and are therefore essential for the control of vascular functions including vasoreactivity and cell proliferation [3]. There is now accumulating evidence indicating that $\mathrm{Cx}$ may play a role in a variety of vascular diseases including systemic arterial hypertension [4]. For instance, elevated pressure has been shown to increase the expression of Cx 43 in
C Biomed Central

(c) 2011 Billaud et al; licensee BioMed Central Ltd. This is an Open Access article distributed under the terms of the Creative Commons Attribution License (http://creativecommons.org/licenses/by/2.0), which permits unrestricted use, distribution, and reproduction in any medium, provided the original work is properly cited. 
cultured cells from aorta [5]. However, the role of gap junctions in pulmonary hypertension $(\mathrm{PH})$ remains largely unknown.

$\mathrm{PH}$ is a multifactorial disease characterized by a progressive increase in pulmonary vascular resistance caused by vasoconstriction, vascular cell proliferation and obliteration of pulmonary microvasculature. These processes lead to right heart failure and ultimately to death [6]. PH occurs in a variety of clinical situations and is associated with a broad spectrum of histological patterns and molecular abnormalities. Because of this diversity, early diagnosis is difficult and efficient treatments are still lacking. The recent revision of the classification of $\mathrm{PH}$ distinguishes five groups [7]. Among these groups, the category $1 \mathrm{PH}$ also known as pulmonary arterial hypertension (PAH) includes idiopathic $\mathrm{PAH}$, familial PAH and acquired PAH, the latter of which being associated with other diseases such as HIV or connective tissue diseases. The non-category $1 \mathrm{PH}$ previously known as secondary $\mathrm{PH}$ includes the category 3 which is a widely distributed PH secondary to alveolar hypoxia as a result of lung disease such as chronic obstructive pulmonary disorder (COPD). Although, $\mathrm{PH}$ has progressively evolved from a fatal to a chronic disease, none of the currently available therapies is curative [8]. Despite intensive research, $\mathrm{PH}$ remains an important medical challenge and a better knowledge of the underlying molecular and cellular mechanisms remains crucial for the development of new or additional innovative therapies.

To comprehensively address the issue of the role of gap junction in $\mathrm{PH}$, we have used two different rat models, the hypoxia and monocrotaline-induced models that share pathophysiological characteristics with category 3 and category $1 \mathrm{PH}$, respectively. Like category 1 and $3 \mathrm{PH}$ patients, monocrotaline- and the chronic hypoxiatreated rats (MCT and $\mathrm{CH}$ rats respectively) exhibit high circulating concentrations of serotonin (5-HT), endothelin-1 (ET-1) and norepinephrine (an adrenoceptor agonist) [9-14]. These increased concentrations of 5-HT, ET-1 and norepinephrine participate to the increase in pulmonary vascular tone [14-16]. Moreover, reduced expression of a variety of potassium channels and mainly voltage-gated and calcium-activated potassium channels leads to membrane depolarisation, voltage-gated calcium channel opening and cytosolic calcium increase in rat and patients with $\mathrm{PH}[15,17]$. The resulting intracellular calcium increase participates to the high pulmonary arterial vascular tone observed in $\mathrm{PH}$.

In the normal pulmonary arterial wall, we have recently demonstrated a functional role of gap junctions in contractile and calcium responses to 5-HT [18]. The aim of the present study was thus to examine the role of gap junctions in the abnormal pulmonary arterial wall in PH. We have demonstrated that $\mathrm{Cx} 37,40$ and 43 are expressed in intrapulmonary arteries (IPA) from the normoxic $(\mathrm{N})$, chronic hypoxia $(\mathrm{CH})$ and $\mathrm{MCT}$ rats and that $\mathrm{Cx} 43$ is overexpressed in $\mathrm{CH}$ rats. By using $\mathrm{Cx}$-mimetic peptides as blockers of gap junctions $[18,19]$, we also highlight the role of $\mathrm{Cx}$ in the contractile responses to stimuli, already known to be involved in $\mathrm{PH}$, namely 5-HT, ET-1, phenylephrine (an $\alpha 1$ adrenoceptor agonist, Phe) and depolarising solutions (high potassium solutions).

\section{Methods}

\section{Animal models of $\mathrm{PH}$}

Male Wistar rats (300-400 g) were separated into 3 groups: the first group (control or normoxic rats - N rats) was housed in ambient room air, the second group (chronic hypoxic rats - $\mathrm{CH}$ rats) was exposed to chronic hypoxia for 3 weeks in a hypobaric chamber $(50 \mathrm{kPa})$ and the third group was injected with a single intraperitoneal dose of monocrotaline (60 mg. $\left.\mathrm{kg}^{-1}\right)$ (MCT rats) and used 4 weeks later. MCT (Sigma, St Quentin Fallavier, France) was dissolved in an equal volume of $\mathrm{HCl}$ $(1 \mathrm{M})$ and $\mathrm{NaOH}(1 \mathrm{M})$. We checked that an injection of an equal volume of isotonic saline solution did not modify the pulmonary arterial reactivity to agonists. All animal care and experimental procedures complied with the recommendations of the Federation of European Laboratory Animals Science Association, and were approved by the local ethics committee (Comité d'éthique régional d'Aquitaine - referenced AP 2/11/2005).

$\mathrm{PH}$ was assessed by measuring both the mean pulmonary arterial pressure (mean PAP) and right ventricle hypertrophy. To measure PAP, N, CH and MCT rats were anesthetized with xylazine $10 \mathrm{mg} \cdot \mathrm{kg}^{-1}$ and ketamine $50 \mathrm{mg} \cdot \mathrm{kg}^{-1}$ by intraperitoneal injection and mean PAP was measured, in closed-chest rats, through a catheter inserted in the right jugular vein, then through the right atria and the right ventricle into the pulmonary artery, and attached to a Baxter Uniflow gauge pressure transducer. Pressure was recorded with an automatic monitor (Physiogard SM 785, ODAM, Wissembourg, France) [20]. Right ventricle hypertrophy was estimated by the ratio of right ventricle (RV) to left ventricle plus septum $(\mathrm{LV}+\mathrm{S})$ weight (Fulton's index).

\section{Tissue Preparation}

Rats were sacrificed using $\mathrm{CO}_{2}$ asphyxia according to the animal care and use local committee (Comité d'éthique régional d'Aquitaine - referenced AP 2/11/2005). The left lung was rapidly removed and rinsed in Krebs solution containing (in mM): $118.4 \mathrm{NaCl}, 4.7 \mathrm{KCl}, 1.2 \mathrm{MgSO}_{4}, 25$ $\mathrm{NaHCO}_{3}, 1.2 \mathrm{KH}_{2} \mathrm{PO}_{4}, 2.5 \mathrm{CaCl}_{2}$, and $11.1 \mathrm{D}$-glucose, $\mathrm{pH} 7.4$ with $\mathrm{NaOH}$. Intrapulmonary arteries with an external diameter of 300-350 $\mu \mathrm{m}$ (intrapulmonary artery 
of the third order - IPA3) and 1.5-2 mm (intrapulmonary artery of the first order - IPA1) were then dissected free from surrounding connective tissues under binocular control.

\section{Quantitative RT-PCR RNA Extraction}

IPA from one rat was homogenized using $600 \mu \mathrm{l}$ of Trizol (Invitrogen, Cergy Pontoise, France), then, $120 \mu \mathrm{l}$ of chloroform (Sigma, St Quentin Fallavier, France) was added. RNA was extracted from the aqueous phase after centrifugation at $15,000 \mathrm{~g}$ for $15 \mathrm{~min}$. RNA was precipitated in the presence of isopropanol (Sigma, St Quentin Fallavier, France) at $20^{\circ} \mathrm{C}$ overnight. Pure RNA was obtained by centrifugation at $15,000 \mathrm{~g}$ for $15 \mathrm{~min}$ and was washed with 80\% ethanol (Sigma, St Quentin Fallavier, France). The concentration of RNA was measured spectrophotometrically by GeneQuant RNA/DNA calculator (Amersham Pharmacia, Orsay, France). Total RNA $(1 \mu \mathrm{g})$ was reverse transcribed into cDNA by using AMV reverse transcriptase (Promega, Charbonnièresles-bains, France), RNase inhibitor, and oligo $\mathrm{d}(\mathrm{T})$ as a primer at $42^{\circ} \mathrm{C}$ for $60 \mathrm{~min}$ followed by heating at $94^{\circ} \mathrm{C}$ for $3 \mathrm{~min}$.

\section{Real-time Quantitative Polymerase Chain Reaction (PCR)}

Real-time quantitative PCR was performed with a RotorGene 2000 (Corbett Research, Cortaboeuf, France) as previously described [21]. cDNA from $10 \mathrm{ng}$ of total RNA were added to $0.2 \mu \mathrm{l}$ of $50 \mathrm{X}$ Titanium Taq DNA Polymerase combined to its buffer (Clontech Laboratories, Saint Germain-en-Laye, France), $1 \mathrm{mM}$ dNTP, each of the appropriate primer (Sigma Genosys; see table 1 for concentrations and sequences, St Quentin
Fallavier, France), and 0.5X SYBR Green (Molecular Probes, Cergy Pontoise, France).

PCR conditions used were identical to those used previously [18]. PCR negative controls were systematically made by using water instead of cDNA. All specific primers were designed by using the primer analysis software (Oligo 6.6, Molecular Biology Insights, Cascade, USA). The efficiency of PCR reactions was always more than $90 \%$. Specificity of the amplified PCR products was checked with melting curve analysis and by electrophoresis analysis on a $2 \%$ agarose gel containing SYBR Green.

\section{Western Blot}

IPA3 from 4 rats were homogenized and proteins were extracted as previously described [22]. Such protein extraction from IPA3 was performed from 4 different pools of 4 rats each. Protein extracts were subjected to electrophoresis on a 10\% acrylamid reducing gel, and transferred to polyvinylidene fluoride (PVDF) membranes (Immobilon-P, Millipore, Molsheim, France). The immunoblots were then incubated using rabbit anti-Cx 37, rabbit anti-Cx 40 or mouse anti-Cx 43 (Zymed, Paris, France) overnight at $4^{\circ} \mathrm{C}$. After incubation with appropriate secondary antibodies coupled to horseradish peroxydase (HRP, Santa Cruz, Heidelberg, Germany) for $2 \mathrm{~h}$ at room temperature, immunoblots were then revealed by enhanced chemiluminescence acquired using Kodak Image Station 4000 MM. Band densities were quantified using GeneTool software (SynGene, Cambridge, United Kingdom). Immunoblots were then stripped and revealed with mouse anti $\beta$-actin.

Table 1 Sequences of the primer pairs (S: sense; AS: antisense) for housekeeping genes (GAPDH, HPRT, PLRPO and YWHAZ) and genes of interest (Cx 37, Cx 40 and Cx 43) are shown as well as GenBank accession number, product length, product $\mathrm{Tm}$ and concentrations

\begin{tabular}{|c|c|c|c|c|c|}
\hline Gene & Sequence & GenBank accession number & Product length $(\mathrm{pb})$ & Product $\operatorname{Tm}\left({ }^{\circ} \mathrm{C}\right)$ & Concentration (nM) \\
\hline \multirow[t]{2}{*}{ GAPDH } & S: ATTCTACCCACGGCAAGTT & NM_017008 & 153 & 89.4 & 200 \\
\hline & AS: CGCCAGTAGACTCCACGACATA & & & & \\
\hline \multirow[t]{2}{*}{ HPRT } & S: TGTTGGATATGCCCTTGACTA & NM_012583 & 178 & 85.6 & 100 \\
\hline & AS: AGATGGCCACAGGACTAGAAC & & & & \\
\hline \multirow[t]{2}{*}{ PLRPO } & S: AGGTGGGAGCCAGCGAAGC & NM_022402 & 208 & 91.7 & 100 \\
\hline & AS: GCAACAGTCGGGTAGCCAATC & & & & \\
\hline \multirow[t]{2}{*}{ YWHAZ } & S: AGCCGAGCTGTCTAACGAG & NM_013011 & 291 & 88.4 & 100 \\
\hline & AS: GCCAAGTAGCGGTAGTAGTCA & & & & \\
\hline \multirow[t]{2}{*}{ Cx 37} & S: GGTGGCAGAGGACGGTCGTCT & NM_021654 & 133 & 85.3 & 200 \\
\hline & AS: CCATGGTCCAGCCGTAGAGA & & & & \\
\hline \multirow[t]{2}{*}{$C \times 40$} & S: GGAAAGAGGTGAACGGGAAG & NM_01280 & 197 & 91.3 & 200 \\
\hline & AS: GGGCCTCGAGACATAACAGTT & & & & \\
\hline \multirow[t]{2}{*}{ Cx 43} & S:TCTGCCTITCGCTGTAACACT & NM_012567 & 117 & 87.5 & 200 \\
\hline & AS: GGGCACAGACACGAATATGAT & & & & \\
\hline
\end{tabular}




\section{Immunofluorescence}

Immunolabelling of IPA3 isolated from N, MCT and $\mathrm{CH}$ rats was performed as previously described [18]. IPA3 were fixed and cut in $10 \mu \mathrm{m}$ sections with a cryostat. Sections were first incubated in blocking buffer containing 0.1\% Triton-X100 (Sigma, St Quentin Fallavier, France) and 1\% bovine serum albumin (BSA) in $\mathrm{PBS}$ for $1 \mathrm{~h}$ at room temperature and then in the primary antibodies (same antibodies as the ones used for Western Blot) overnight at $4^{\circ} \mathrm{C}$. Sections were then incubated with the appropriate secondary antibodies coupled to Alexa 546 (Molecular Probes, Cergy Pontoise, France). Nuclei were labeled with $45 \mu \mathrm{M}$ Hoechst 33342 (Molecular Probes, Cergy Pontoise, France). Sections were then observed with a laser scanning confocal microscope TE2000 (Nikon, Champigny-Sur-Marne, France) with a $\times 60,1.40$ NA plan apochromat oilimmersion objective. Excitation was obtained with a diode laser at $408 \mathrm{~nm}$ to observe nuclei, an argon laser at $488 \mathrm{~nm}$ to observe autofluorescence of the internal and external elastic lamina and a helium-neon laser at $543 \mathrm{~nm}$ to observe Cx labelling. The emitted light was filtered as appropriate: $450 \pm 35 \mathrm{~nm}$ for nuclei (blue), $515 \pm 30 \mathrm{~nm}$ for internal elastic lamina (green), and $605 \pm 75 \mathrm{~nm}$ for Cx labelling (red).

\section{Isometric tension measurements}

IPA1 were divided into short tubular segments with an external diameter of $1.5-2 \mathrm{~mm}$ and used for isometric contraction measurement as reported previously [23]. Arterial rings were mounted in isolated organ bath systems, containing Krebs solution at $37^{\circ} \mathrm{C}$ and bubbled continuously with either $15 \% \mathrm{O}_{2}, 5 \% \mathrm{CO}_{2}$ for IPA1 isolated from $\mathrm{N}$ and MCT rats, or with $9 \% \mathrm{O}_{2}, 5 \% \mathrm{CO}_{2}$ for IPA1 isolated from $\mathrm{CH}$ rats. As previously determined [22], an initial load of $0.8 \mathrm{~g}$ was applied to arterial rings isolated from control rats, and $1.6 \mathrm{~g}$ to arterial rings isolated from $\mathrm{CH}$ and MCT rats. Tissues were allowed to equilibrate for $1 \mathrm{~h}$ in Krebs solution and washed out every $15 \mathrm{~min}$. A high $\mathrm{KCl}$ solution $(80 \mathrm{mM})$ was applied in order to obtain a reference contraction used to normalize subsequent contractile responses. $80 \mathrm{mM}$ high $\mathrm{KCl}$ solution induced similar contractions in pulmonary arterial rings from the three rat models $(1036 \pm 50 \mathrm{mg}$, $\mathrm{n}=67 ; 1205 \pm 143 \mathrm{mg}, \mathrm{n}=64 ; 953 \pm 54 \mathrm{mg}, \mathrm{n}=68 \mathrm{in}$ $\mathrm{N}, \mathrm{CH}$ and MCT rats respectively; $P>0.05$ ). Contractile responses to different agonists were then tested by constructing a cumulative concentration-response curve (CCRC) to 5 -HT (10 nM to $100 \mu \mathrm{M})$, ET-1 (0.1 to $100 \mathrm{nM})$, Phe $(0.1 \mathrm{nM}$ to $10 \mu \mathrm{M})$ or high $\mathrm{KCl}$ solutions (4.7 to $100 \mathrm{mM}$ ). We inhibited gap junction communications through $C x 37$ and $C x 43$ or $C x 40$ with $300 \mu \mathrm{M}$ synthetic connexin-mimetic peptides: ${ }^{37-43} \mathrm{Gap}$ 27 (SRPTEKTIFII; Peptide 2.0 Inc, Shirley, USA), ${ }^{40}$ Gap
27 (SRPTEKNVFIV; Genscript, Piscataway, USA) respectively $[18,19]$. When indicated, peptides were preincubated during $1 \mathrm{~h}$, and then CRC to agonist was performed in the presence of the peptide. Specificity of these peptides was checked in a previous study [18]. High potassium solutions were obtained by substituting an equimolar amount of $\mathrm{KCl}$ for $\mathrm{NaCl}$ from Kreb's solution. To determine the role of the gap junctions in conditions close to physiological conditions, we studied the vessels with intact endothelium. Endothelial function was tested on each ring by examining the relaxation induced by $10 \mu \mathrm{M}$ carbamylcholine on $0.3 \mu \mathrm{M}$ Pheinduced preconstricted pulmonary arterial rings. Passive and active mechanical properties were assessed using transducer systems, coupled to IOX software (EMKA technologies, Paris, France) in order to facilitate data acquisition and analysis [23].

\section{Data analysis and statistics}

Results are expressed as mean \pm SEM; $n$ indicates the number of rats for quantitative RT-PCR, Fulton ratio and mean PAP whereas it indicates the number of experiments from 4 pools of rats (4 rats per pool) for Western Blot. For isometric tension measurements, $\mathrm{n}$ indicates the number of pulmonary arterial rings. CCRC to agonists were fitted using Origin 6 software (Originlab, Paris, France) to the logistic equation: $\mathrm{T}=\left((\mathrm{T} 0-\mathrm{Tmax}) /\left(1+\left(\mathrm{X} / \mathrm{EC}_{50}\right) \mathrm{p}\right)\right)+\mathrm{Tmax}$ where $\mathrm{T}$, Tmax and $\mathrm{T} 0$ are, respectively, the amplitude of tension developed, the relative maximum and minimal tensions for a given agonist concentration normalized to the $80 \mathrm{mM} \mathrm{KCl}$ responses, $\mathrm{X}$ is the concentration of agonist used, $\mathrm{EC}_{50}$ is the concentration of agonist which produces half maximal tension, and $\mathrm{p}$ is the slope of the curve. Global comparisons of the CCRC were performed using ANOVA. When global comparisons of the curves were significantly different, unpaired Student's t tests were performed on maximal effect (Emax) and/or $\mathrm{EC}_{50}$. $\mathrm{EC}_{50}$ was determined only when the maximal contraction was achieved. Quantitative RT-PCR results were analyzed with the GeNorm method [18]. Statistical analyses were performed on all other data using a non parametric test for unpaired samples (Mann-Whitney test). A value of $P<$ 0.05 was considered significant.

\section{Results}

Assessment of pulmonary hypertension in two rat models The mean PAP value was significantly increased from $15 \pm 2 \mathrm{mmHg}$ in $\mathrm{N}$ rats $(\mathrm{n}=5)$ to $30.4 \pm 1.03 \mathrm{mmHg}$ in $\mathrm{CH}$ rats $(\mathrm{n}=5)$ or $29.8 \pm 1.3 \mathrm{mmHg}$ in MCT rats $(\mathrm{n}$ $=5$ ). The Fulton's index was also significantly increased in each pulmonary hypertensive rat model indicating a right ventricle hypertrophy in $\mathrm{CH}$ and $\mathrm{MCT}$ rats compared to $\mathrm{N}$ rats $(0.63 \pm 0.04, \mathrm{n}=20 ; 0.54 \pm 0.03, \mathrm{n}=20$ and $0.27 \pm 0.03, \mathrm{n}=20$ respectively). 
To differentiate MCT from $\mathrm{CH}$ rat models, we examined the endothelial NO-dependent function by inducing a relaxation with $10 \mu \mathrm{M}$ carbamylcholine on $0.3 \mu \mathrm{M}$ Pheinduced preconstricted pulmonary arterial rings. Relaxation to carbamylcholine $10 \mu \mathrm{M}$ was not significantly changed in $\mathrm{CH}$ compared to $\mathrm{N}$ rats whereas it was almost abolished in MCT rats $(58.1 \pm 3.0 \%$ and $3.3 \pm 0.9 \%$ of the precontraction to $0.3 \mu \mathrm{M}$ Phe in $\mathrm{CH}$ and MCT rats respectively, $\mathrm{n}=$ 48 and 44 vs $64.1 \pm 2.9 \%$ in $\mathrm{N}$ rats, $\mathrm{n}=48$ ).

\section{Cx 37,40 and 43 are expressed in the pulmonary arterial wall from $\mathrm{N}, \mathrm{CH}$ and $\mathrm{MCT}$ rats}

Quantitative RT-PCR and Western Blot experiments have demonstrated the presence of the mRNA and proteins, respectively for $\mathrm{Cx} 37,40$ and 43 in IPA3 from $\mathrm{N}, \mathrm{CH}$ and $\mathrm{MCT}$ rats (Figure $1 \mathrm{~A}$ and $1 \mathrm{~B}$ respectively). Interestingly, a significant increase in both mRNA and protein levels was observed for the $\mathrm{Cx} 43$ in IPA3 from $\mathrm{CH}$ rats compared to IPA3 from $\mathrm{N}$ rats (Figure 1A and 1B, left panels).

Immunofluorescent labelling studies confirmed the presence of the Cx 37, 40 and 43 proteins (Figure 2). The autofluorescence of the external and internal elastic lamina in green allowed us to delimit the smooth muscle layers from the endothelial cells and the adventitia as previously observed [18]. The three connexins were mainly present in the endothelial and possibly in the myoendothelial junctions (Figure 2). Some punctuate labelling, characteristic of the Cx staining, was also sparsely present for $\mathrm{Cx} 37$ and 40 in the smooth muscle of IPA3 from N and MCT rats (Figure 2). Since identical antibodies were used for Western Blot and immunofluorescent labelling experiments, the typical punctuate labelling observed demonstrate the specificity of these $\mathrm{Cx}$ antibodies and strengthen our Western Blot results.

\section{Comparison of the pulmonary arterial reactivity to various stimuli in $\mathrm{N}, \mathrm{CH}$ and $\mathrm{MCT}$ rats}

We then compared contractile responses to receptordependent or -independent stimuli such as (1) 5-HT, (2) ET-1, (3) Phe, an agonist of the $\alpha 1$-adrenoceptor and (4) a depolarising agent such as high potassium solutions in IPA from N, CH and MCT rats. The contractile responses to 5 - $\mathrm{HT}$ and high potassium solutions were significantly increased in $\mathrm{CH}$ rats (Figure 3A and 3D) whereas those to ET-1 were significantly decreased in both pulmonary hypertensive rat models $(\mathrm{CH}$ and $\mathrm{MCT}$ rats, Figure 3B). Finally, contractile responses to Phe were significantly increased in MCT rats (Figure 3C).

\section{Role of $\mathrm{Cx} 37,40$ and 43 in the reactivity to various stimuli in intrapulmonary arteries from $\mathrm{N}, \mathrm{CH}$ and MCT rats}

Since, (1) Cx 37, 40 and 43 are all expressed (Figure 1 and 2) and (2) 5-HT, ET-1, Phe and depolarisation induce a mechanical activity (Figure 3) in intrapulmonary arteries from $\mathrm{CH}$ and MCT rats, we systematically addressed the role of $\mathrm{Cx} 37,40$ and 43 in the isometric contraction to 5-HT, ET-1, Phe and high potassium solutions by using specific blockers of Cx 40 or Cx 37 and 43 (namely ${ }^{40} \mathrm{Gap} 27$ and ${ }^{37-43} \mathrm{Gap} 27$ respectively, two $\mathrm{Cx}$-mimetic peptides) in IPA from $\mathrm{N}, \mathrm{CH}$ and $\mathrm{MCT}$ rats.

Contractile responses to 5 - $\mathrm{HT}$ were significantly decreased by $300 \mu \mathrm{M}^{37-43} \mathrm{Gap} 27$ only in IPA from $\mathrm{N}$ rats (Figure 4A). In IPA from either rat model, the contractile responses to ET-1 were unchanged following one hour incubation with $300 \mu \mathrm{M}{ }^{37-43} \mathrm{Gap} 27$ or ${ }^{40}$ Gap27 (Figure 5). Interestingly, and inversely to 5-HT, contractile responses to Phe were decreased following $300 \mu \mathrm{M}{ }^{37-43} \mathrm{Gap} 27$ or ${ }^{40} \mathrm{Gap} 27$ treatment in IPA from $\mathrm{CH}$ and $\mathrm{MCT}$ rats (Figure $6 \mathrm{~B}, \mathrm{C}$ and 6D, E respectively). In $\mathrm{N}$ rats, contractile responses to Phe were unchanged by ${ }^{37-43} \mathrm{Gap} 27$ or ${ }^{40} \mathrm{Gap} 27$ incubation (Figure 6A). The effects of the ${ }^{37-43} \mathrm{Gap} 27$ and ${ }^{40} \mathrm{Gap} 27$ on contractile changes from $\mathrm{N}$ to $\mathrm{CH}$ rats and from $\mathrm{N}$ to $\mathrm{MCT}$ rats are demonstrated in figure $6 \mathrm{C}$ and $6 \mathrm{E}$ respectively.

When using a receptor-independent depolarising agent (high potassium solutions), contractile responses were significantly decreased in the presence of $300 \mu \mathrm{M}$ ${ }^{37-43}$ Gap27 only in IPA from $\mathrm{CH}$ rats (Figure $7 \mathrm{~B}$ ). $\mathrm{EC}_{50}$ was significantly increased in the presence of ${ }^{37-43} \mathrm{Gap} 27$ in IPA from $\mathrm{CH}$ rats $(40.2 \pm 0.5 \mathrm{mM}$ vs $15 \pm 1.1 \mathrm{mM}$ in the absence of ${ }^{37-43} \mathrm{Gap} 27$ ) indicating a decrease in the sensitivity to high potassium solutions. $300 \mu \mathrm{M}{ }^{40} \mathrm{Gap} 27$ had no effect, under identical conditions, in any of the hypertensive rat models used (Figure 7B and 7D). In the presence of the ${ }^{37-43} \mathrm{Gap} 27$, the contraction to $\mathrm{KCl}$ in $\mathrm{CH}$ rats was identical to the contraction to $\mathrm{KCl}$ in $\mathrm{N}$ rats (Figure $7 \mathrm{C}$ ).

\section{Discussion}

Underlying cellular mechanisms as well as targets, governing the pathogenesis of $\mathrm{PH}$, still remain to be fully elucidated. This may be due, at least in part, to the fact that the pathogenesis of $\mathrm{PH}$ differs depending on the type of aetiology of this vascular disorder. For this reason, we conducted the present study in two different PH models: MCT induced PH (non hypoxic model) and $\mathrm{CH}$-induced $\mathrm{PH}$ (hypoxic model).

Two major excitation-contraction coupling mechanisms are involved in regulating pulmonary vascular tone: electromechanical and pharmacomechanical coupling. We thus adressed agonist-mediated pulmonary contraction (pharmacomechanical coupling induced by either 5-HT, ET-1 or Phe) and depolarisation-mediated contraction (electromechanical coupling induced by high potassium solution). In the present study, IPA from $\mathrm{CH}$ rats exhibited hyperreactivity to 5-HT (Figure 3A), 


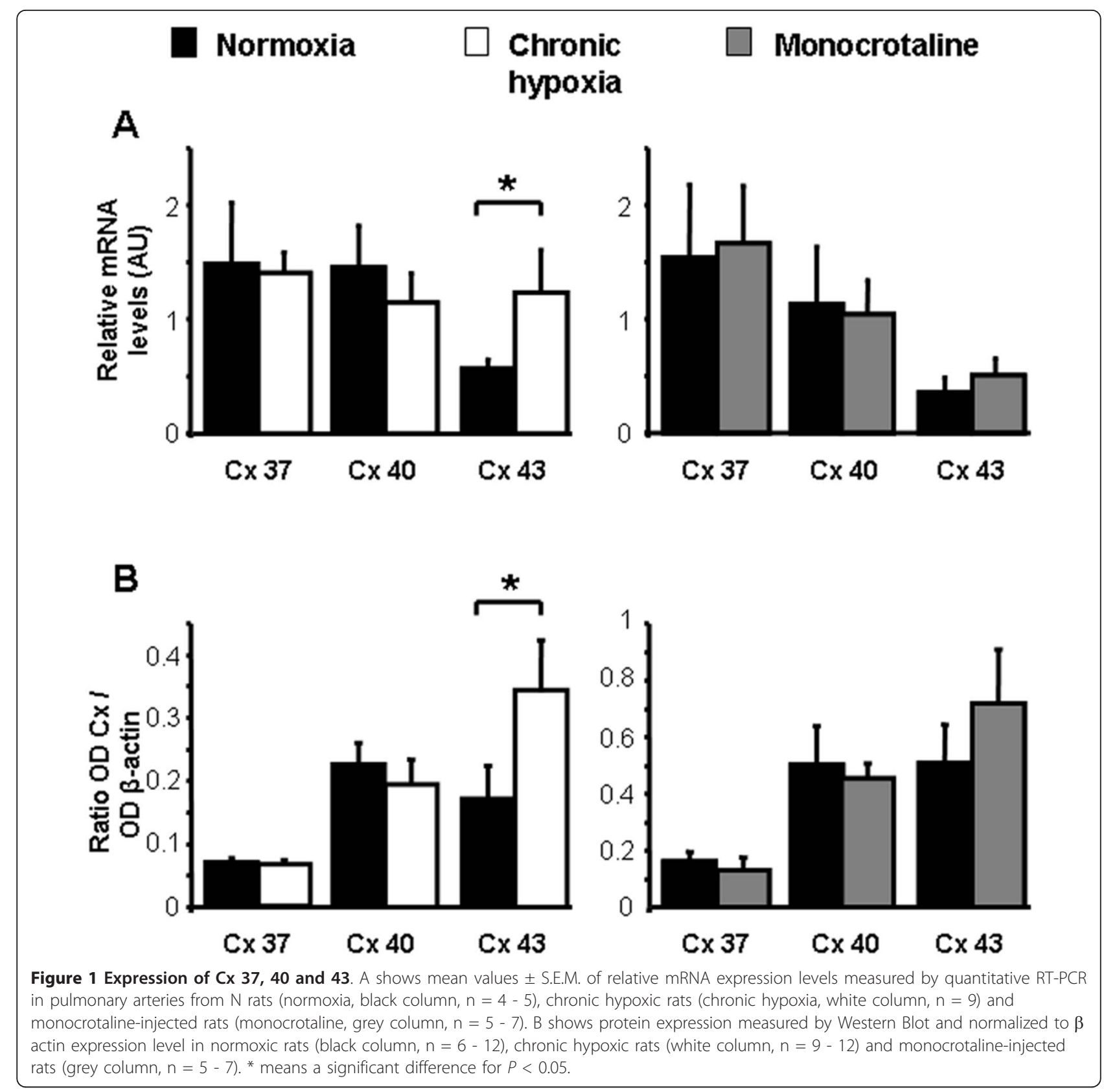

which is consistent with previous studies [22,24,25]. Regarding ET-1, vasoconstriction to this agent was only slightly decreased in hypoxic $\mathrm{PH}$ whereas it was dramatically decreased in MCT-induced $\mathrm{PH}$. In $\mathrm{CH}$ rats, pulmonary arterial contractile responses to ET-1 have been shown to be increased in resistant IPA but decreased in extra pulmonary arteries [16]. Consequently, the slight decrease in the contraction to ET-1 observed in $\mathrm{CH}$ rats may be explained by the intermediate size of the pulmonary artery (PA) used for the present contractile experiments (namely PA of the first order or IPA1). In MCT rats, a recent study has shown that although the contraction to ET-1 was not altered, ET-B receptors were decreased in resistance PA [26]. Since the contraction to ET-1 is linked to ET-A receptors in extra-PA and to ET-B receptors in IPA $[26,27]$, the present decreased ET-1 contraction may result from the reported decrease in ET-B receptors in MCT rats. Regarding Phe and in contrast to ET-1, we found that Phe-induced contraction was increased in PA from MCT rats. A recent report from Mam et al. (2010) showed a reduced contraction to Phe in $\mathrm{CH}$ and MCT rats [28]. This difference may be explained by different animal strain (Sprague Dawley vs Wistar rats) and/or 


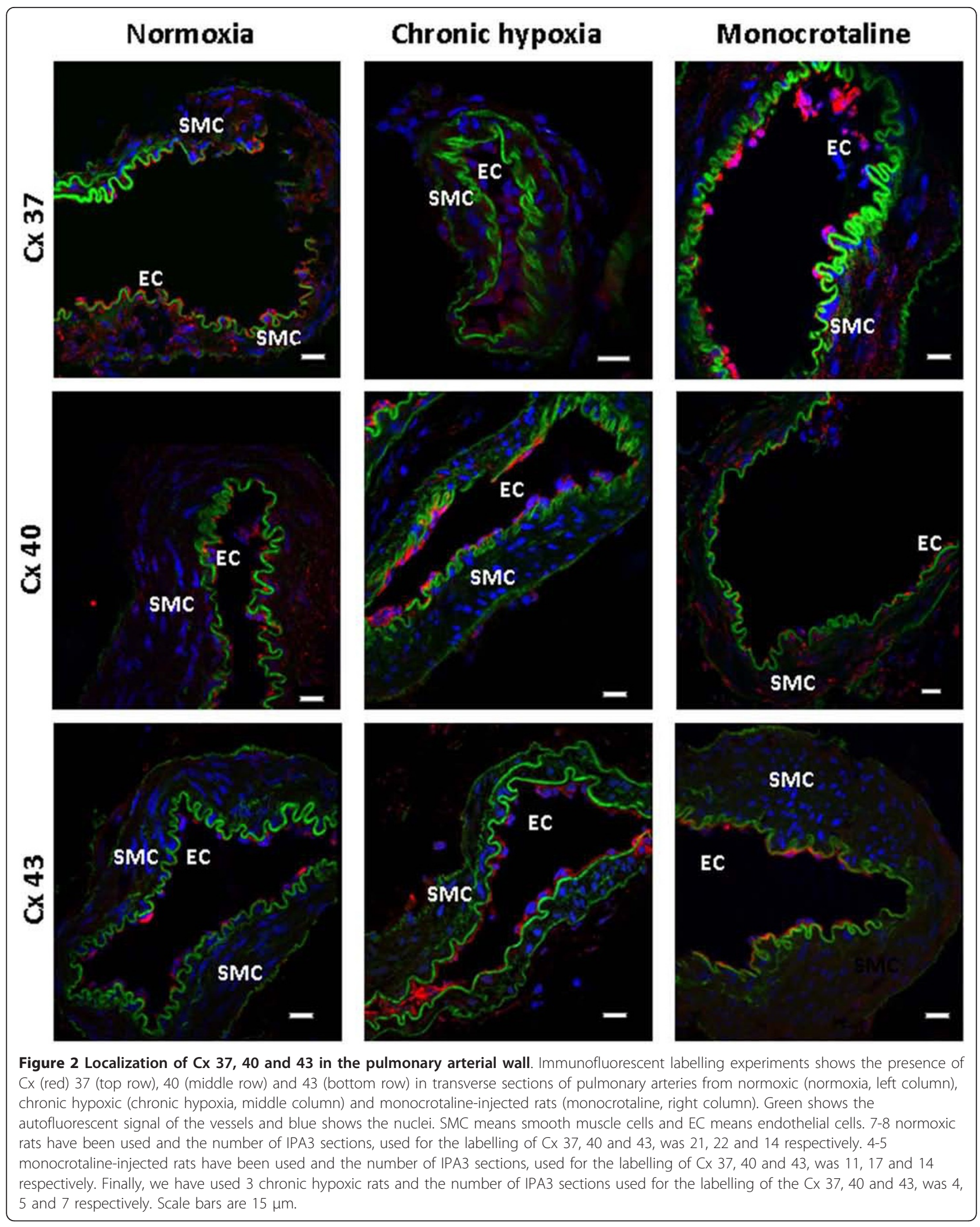




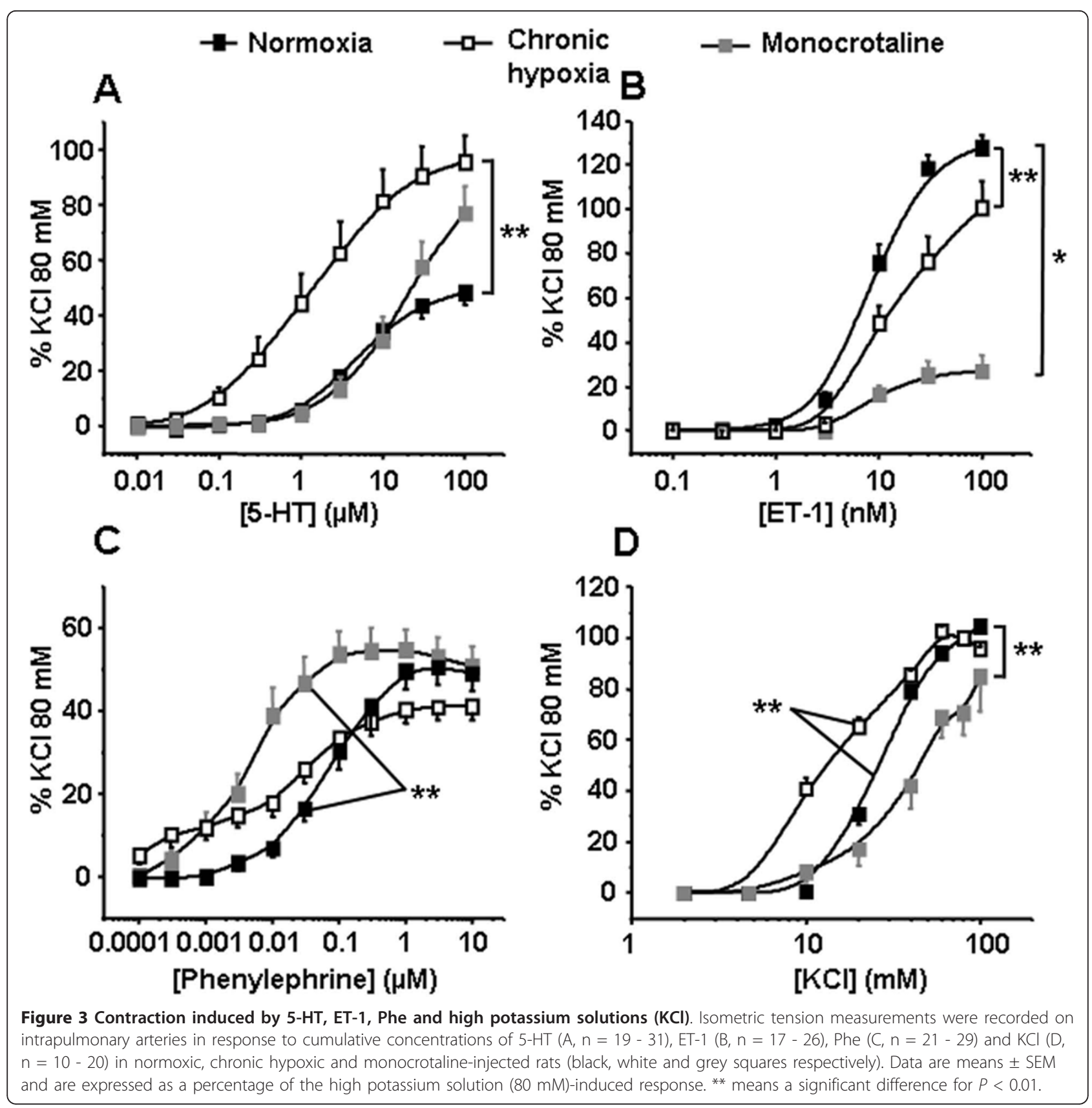

different vascular preparation (extra-PA vs IPA) and/or different experimental conditions (normobaric vs hypobaric hypoxia). Finally, regarding the receptor independent depolarizing agent $\mathrm{KCl}$, pulmonary vascular reactivity to membrane depolarization was increased in $\mathrm{CH}$ rats, whereas it was reduced in MCT rats. These results are consistent with previous findings from our laboratory indicating that PA smooth muscle cells (PASMC) from $\mathrm{CH}$ rats exhibit a higher resting membrane potential and a higher basal intracellular calcium concentration [22,29]. Moreover, the decreased expression of potassium channels previously observed in $\mathrm{CH}$ rats [17] could also contribute to increase the sensitivity to depolarisation.

We have previously shown that $C x 37,40$ and 43 , three gap junction proteins commonly found in the vasculature, are expressed in rat PA endothelial cells, while Cx 37 and 40 only are found in PASMC [18]. In the current study, Cx 37, 40 and 43 were also expressed in pulmonary arterial wall from both hypoxic and nonhypoxic $\mathrm{PH}$ rats. However, PASMC from $\mathrm{CH}$ rats no longer expressed $\mathrm{Cx} 37$ and 40 isoforms, whereas they 

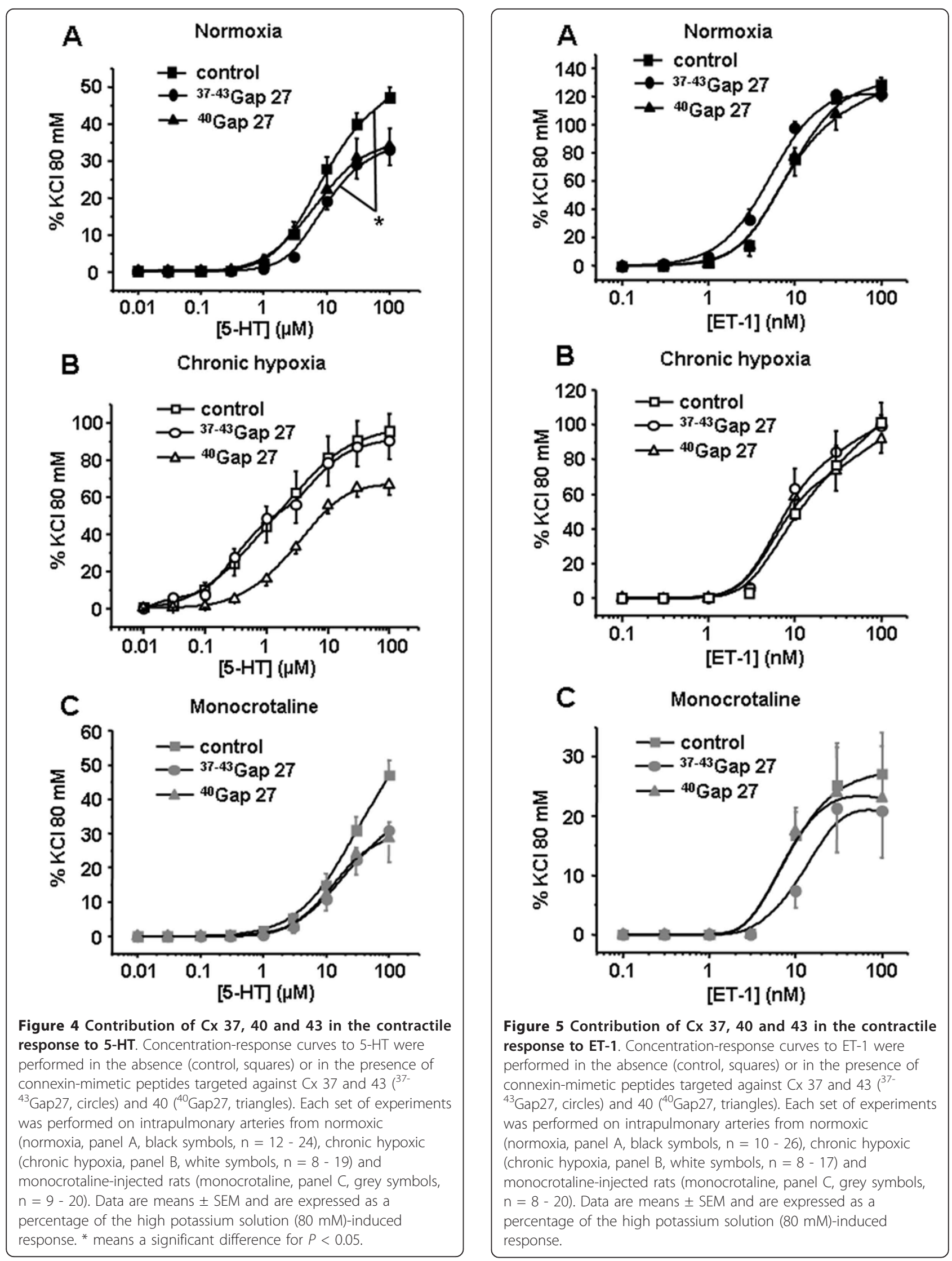


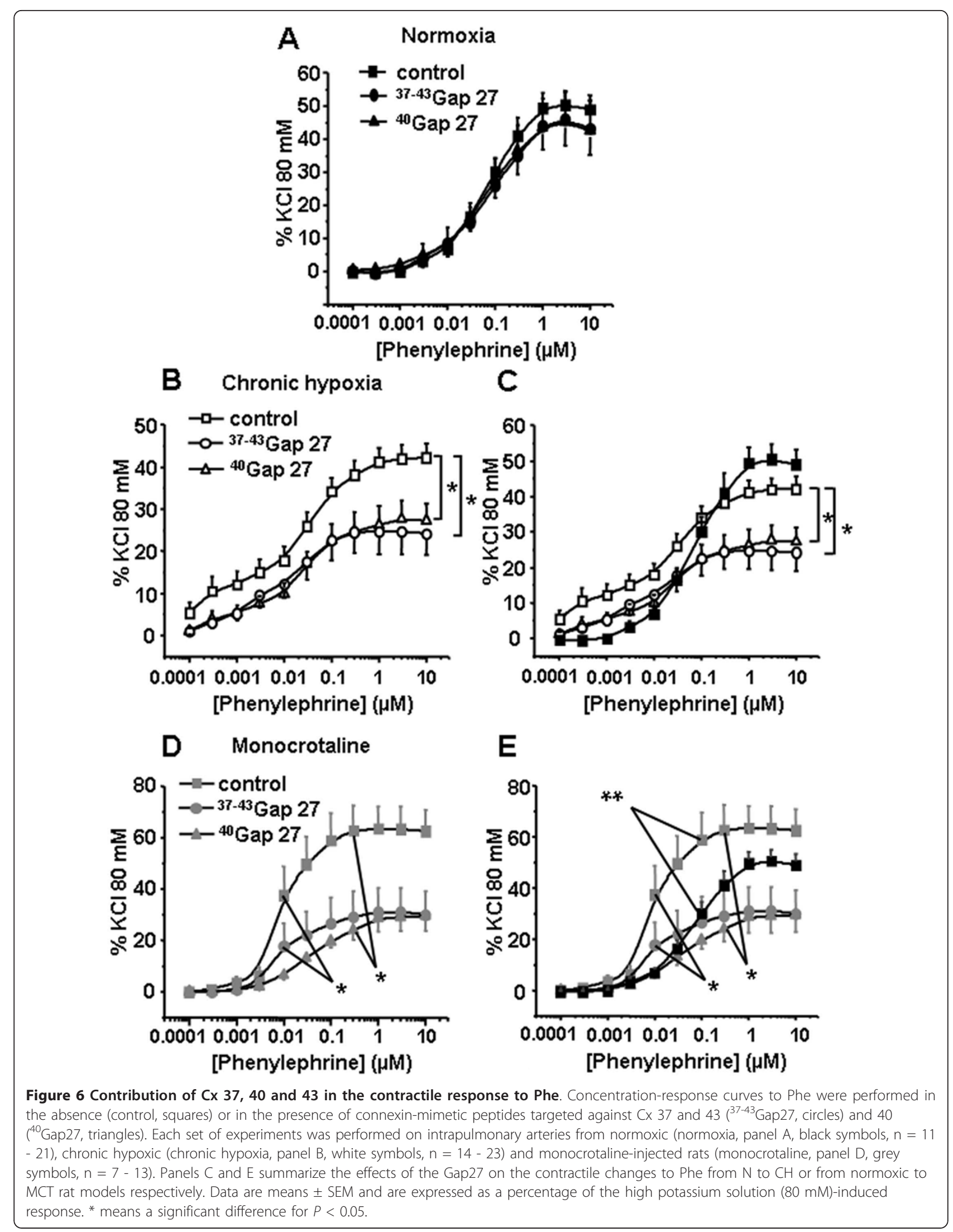




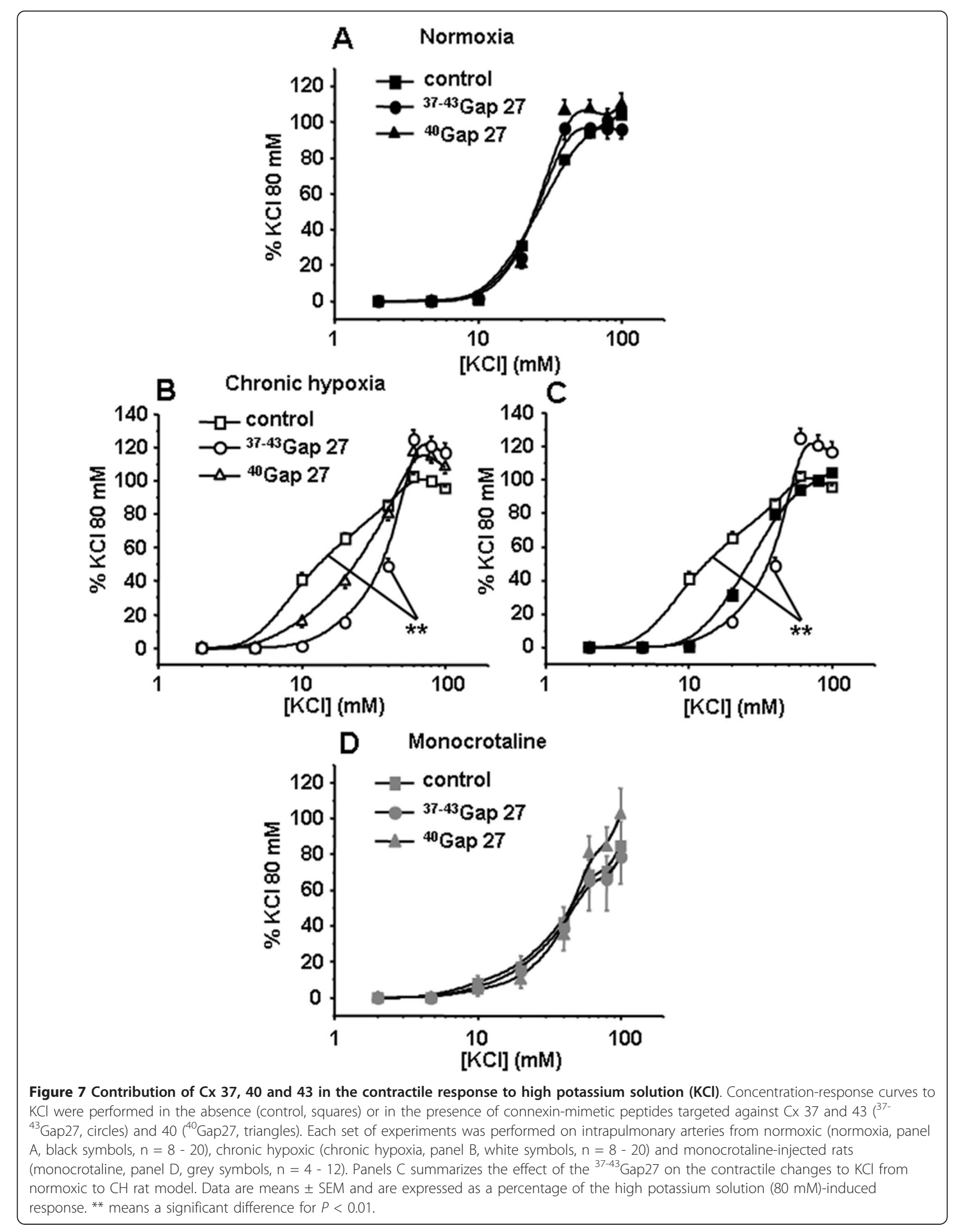


were sparsely expressed in MCT rats (Figure 2). Interestingly, $\mathrm{Cx} 43$ expression was upregulated in $\mathrm{CH}$ rats but not in MCT rats (Figure 1). We cannot exclude that Cx 43 is expressed at the myoendothelial junctions and possibly on the smooth muscle side of these heterocellular structures. Cowan et al. have indeed demonstrated that hypoxia $\left(2.2 \% \mathrm{O}_{2}\right.$ during $\left.6 \mathrm{~h}\right)$ increased $\mathrm{Cx} 43$ expression in cultured smooth muscle cells from rat thoracic aorta [5]. Consequently, we can hypothesize that the increase in $\mathrm{Cx} 43$ in the IPA from $\mathrm{CH}$ rat could be due to the effect of hypoxia on $\mathrm{Cx} 43$ localized on the smooth muscle side of the myoendothelial gap junctions. Interestingly, we have previously demonstrated that Cx 43 present between PASMC and endothelial cells plays an important role in the vasoreactivity to 5HT in IPA from $\mathrm{N}$ rats [18].

Since (i) the three $\mathrm{Cx} 37,40$ and 43 are expressed in $\mathrm{CH}$ and MCT rats (Figure 1 and 2) and (ii) $\mathrm{Cx} 37$ and 43 are involved in the contractile and calcium responses to 5-HT in IPA from $\mathrm{N}$ rats [18], we addressed the role of these $\mathrm{Cx}$ in the contractile response to various agonists known to contribute to PH (5-HT, ET-1 and Phe) in IPA from $\mathrm{CH}$ and MCT rats. In the present study, the effect of Gap27 varied according to the agonists used and the rat model considered. Since we have previously demonstrated that the role of the gap junctions in the contraction depended on the amount of superoxide anion $\left(\mathrm{O}_{2}^{\bullet}\right)$ level in smooth muscle, it can be hypothesized that the modulation of $\mathrm{O}_{2}{ }_{-}^{\bullet}$ level in IPA from hypertensive rat models may differ according to the agonist. In this respect, we can suggest that, unlike 5-HT, Phe increases $\mathrm{O}_{2}{ }^{\bullet}$ levels in pulmonary hypertensive models and not in $\mathrm{N}$ rats although this hypothesis would require further experimental investigation.

Moreover, 5-HT, ET-1 and Phe are pulmonary arterial vasoconstrictors with different modes of actions. Smooth muscle contraction is well known to be both dependent and/or independent on cytosolic calcium increase depending on the vasoconstrictor. When smooth muscle contraction is calcium independant, the contraction is due to calcium sensitization of the contractile proteins. On the one hand, ET-1 and 5-HT increase intracellular calcium by acting on receptors localised in both smooth muscle and endothelial cells (namely $5-\mathrm{HT}_{2 \mathrm{~A}}, 5-\mathrm{HT}_{1 \mathrm{~B} / \mathrm{D}}, \mathrm{ET}_{\mathrm{A}}$ and $\mathrm{ET}_{\mathrm{B}}$ in PASMC and 5- $\mathrm{HT}_{2 \mathrm{~B}}$ and $\mathrm{ET}_{\mathrm{B}}$ in endothelial cells) whereas Phe acts on $\alpha_{1}$-adrenoceptors on PASMC only $[14,21,30,31]$. On the other hand, although 5-HT, ET-1 and Phe activate inositol 1,4,5-triphosphate-induced intracellular calcium release, 5 -HT and Phe also stimulate voltage-independent calcium permeable channels (namely receptor- and/or store-operated channels) whereas ET-1 rather stimulates voltage-dependent calcium channels [32-34]. Finally, contraction to ET-1 and Phe are strongly dependent on calcium sensitization of contractile proteins whereas contraction to 5 -HT is only slightly dependent on this process [21,35-37]. Altogether, such differences in the contractile mechanisms might explain why the effects of the gap junction blockers differ according to the agonist used.

Regarding receptor-independent depolarisation, we have observed a significant decrease in the contraction to $\mathrm{KCl}$ in IPA from MCT rats but an increase in $\mathrm{CH}$ rats (Figure 3D). Moreover, ${ }^{37-43}$ Gap27 decreased the sensitivity to high potassium solutions in IPA from $\mathrm{CH}$ rats only, thus inducing a contraction similar to the one observed in the $\mathrm{N}$ rats (Figure $7 \mathrm{C}$ ). These results suggest that $\mathrm{Cx}$ 37 and/or 43 were involved in the hypersensitivity to $\mathrm{KCl}$ in $\mathrm{CH}$ rats. This result is thus in good agreement with the expected role of $\mathrm{Cx}$ in the conduction of the electrical activity observed in various systemic vessels [38].

\section{Conclusions}

In conclusion, we have evidenced the presence of functional Cx 37, 40 and 43 not only in normal but also in pathological pulmonary vessels. These three Cx participate to pulmonary arterial vascular contractility in response to both receptor-dependent and receptor-independent stimuli in N, $\mathrm{CH}$ and MCT rats. However, the role of these $\mathrm{Cx}$ in the vasoreactivity of pulmonary artery varies according to the stimulus and the rat model. These results suggest that $\mathrm{Cx}$ may act as specific therapeutic targets for different type of $\mathrm{PH}$.

\section{List of used abbreviations}

$\mathrm{CH}$ : chronic hypoxia; COPD: chronic obstructive pulmonary disorder; CRC: concentration-response curve; Cx: connexins; ET-1: endothelin-1; 5-HT: serotonin; IPA: intrapulmonary arteries; IPA1: intrapulmonary artery of the first order; IPA3: intrapulmonary artery of the third order; LV+S: left ventricle plus septum; MCT: monocrotaline-treated; mean PAP: mean pulmonary arterial pressures; $\mathrm{N}$ : normoxic; $\mathrm{O}_{2}^{\bullet}$ : superoxide anion; PA: pulmonary artery; $\mathrm{PAH}$ : pulmonary arterial hypertension; PASMC: pulmonary arterial smooth muscle cells; PH: pulmonary hypertension; Phe: phenylephrine; RV: right ventricle.

\section{Acknowledgements and funding}

We thank Huguette Crevel for her technical assistance in performing isometric contraction experiments.

This work was funded by the Fondation de France (2008002719), the Agence Nationale de la Recherche (ANR06-Physio-015-01) and the Société de Pneumologie de Langue Française (SPLF) - Boerhinger du Fonds de Dotation Recherche en Santé Respiratoire.

The authors declare that they have no competing interests.

\section{Author details}

${ }^{1}$ INSERM, U1045, 146 rue Léo Saignat, F-33076 Bordeaux, France. ${ }^{2}$ Université Bordeaux Segalen, Centre de Recherche Cardio-Thoracique de Bordeaux, F33076 Bordeaux, France. ${ }^{3} \mathrm{CHU}$ de Bordeaux, F 33076 Bordeaux, France.

\section{Authors' contributions}

$M B, D D, R M, J P S$ and $C G$ contributed to the conception and design of the study. MB, DD and CG performed experiments, evaluated results and interpreted data. MB, DD, RM, JPS and CG were involved in drafting and revising the manuscript. All authors read and approved the final manuscript. 
Received: 19 October 2010 Accepted: 17 March 2011

Published: 17 March 2011

\section{References}

1. Goodenough DA, Paul DL: Gap junctions. Cold Spring Harbor Perspect Biol 2009, 1:a002576.

2. Cottrell GT, Burt JM: Functional consequences of heterogeneous gap junction channel formation and its influence in health and disease. Biochim Biophys Acta 2005, 1711:126-141.

3. Brisset $A C$, Isakson BE, Kwak BR: Connexins in vascular physiology and pathology. Antioxid Redox Signal 2009, 11:267-282.

4. Rummery NM, Hill CE: Vascular gap junctions and implications for hypertension. Clin Exp Pharmacol Physiol 2004, 31:659-667.

5. Cowan DB, Jones M, Garcia LM, Noria S, del Nido PJ, McGowan FX Jr: Hypoxia and stretch regulate intercellular communication in vascular smooth muscle cells through reactive oxygen species formation. Arterioscler Thromb Vasc Biol 2003, 23:1754-1760.

6. Humbert M, Sitbon O, Simonneau G: Treatment of pulmonary arterial hypertension. N Engl J Med 2004, 351:1425-1436.

7. Simonneau G, Robbins IM, Beghetti M, Channick RN, Delcroix M, Denton CP, Elliott CG, Gaine SP, Gladwin MT, Jing ZC, Krowka MJ, Langleben D, Nakanishi N, Souza R: Updated clinical classification of pulmonary hypertension. J Am Coll Cardiol 2009, 54:S43-54.

8. Humbert M: Update in pulmonary hypertension 2008. Am J Respir Crit Care Med 2009, 179:650-656.

9. Giaid A, Yanagisawa M, Langleben D, Michel RP, Levy R, Shennib H, Kimura S, Masaki T, Duguid WP, Stewart DJ: Expression of endothelin-1 in the lungs of patients with pulmonary hypertension. N Engl J Med 1993, 328:1732-1739.

10. Herve $P$, Launay JM, Scrobohaci ML, Brenot F, Simonneau G, Petitpretz P, Poubeau P, Cerrina J, Duroux P, Drouet L: Increased plasma serotonin in primary pulmonary hypertension. Am J Med 1995, 99:249-254.

11. Hosoda Y: Pathology of pulmonary hypertension: a human and experimental study. Pathol Int 1994, 44:241-267.

12. Kanai Y, Hori S, Tanaka T, Yasuoka M, Watanabe K, Aikawa N, Hosoda Y: Role of 5-hydroxytryptamine in the progression of monocrotaline induced pulmonary hypertension in rats. Cardiovasc Res 1993, 27:1619-1623.

13. Miyauchi T, Yorikane R, Sakai S, Sakurai T, Okada M, Nishikibe M, Yano M, Yamaguchi I, Sugishita Y, Goto K: Contribution of endogenous endothelin1 to the progression of cardiopulmonary alterations in rats with monocrotaline-induced pulmonary hypertension. Circ Res 1993, 73:887-897.

14. Salvi SS: Alpha1-adrenergic hypothesis for pulmonary hypertension. Chest 1999, 115:1708-1719.

15. Humbert M, Morrell NW, Archer SL, Stenmark KR, MacLean MR, Lang IM, Christman BW, Weir EK, Eickelberg O, Voelkel NF, Rabinovitch M: Cellular and molecular pathobiology of pulmonary arterial hypertension. J Am Coll Cardiol 2004, 43:13S-24S

16. Shimoda LA, Sham JS, Sylvester JT: Altered pulmonary vasoreactivity in the chronically hypoxic lung. Physiol Res 2000, 49:549-560

17. Guibert C, Marthan R, Savineau JP: Modulation of ion channels in pulmonary arterial hypertension. Curr Pharm Des 2007, 13:2443-2455.

18. Billaud M, Marthan R, Savineau JP, Guibert C: Vascular smooth muscle modulates endothelial control of vasoreactivity via reactive oxygen species production through myoendothelial communications. PLoS One 2009, 4:e6432.

19. Chaytor AT, Evans WH, Griffith TM: Peptides homologous to extracellular loop motifs of connexin 43 reversibly abolish rhythmic contractile activity in rabbit arteries. J Physiol 1997, 503(Pt 1):99-110.

20. Tual-Chalot S, Guibert C, Muller B, Savineau JP, Andriantsitohaina R, Martinez MC: Circulating Microparticles from Pulmonary Hypertensive Rats Induce Endothelial Dysfunction. Am J Respir Crit Care Med 2010, 182:261-268.

21. Rodat-Despoix L, Crevel H, Marthan R, Savineau JP, Guibert C: Heterogeneity in 5-HT-induced contractile and proliferative responses in rat pulmonary arterial bed. J Vasc Res 2008, 45:181-192.

22. Rodat L, Savineau JP, Marthan R, Guibert C: Effect of chronic hypoxia on voltage-independent calcium influx activated by $5-\mathrm{HT}$ in rat intrapulmonary arteries. Pflugers Arch 2007, 454:41-51.

23. Guibert C, Savineau JP, Crevel H, Marthan R, Rousseau E: Effect of shortterm organoid culture on the pharmaco-mechanical properties of rat extra- and intrapulmonary arteries. Br J Pharmacol 2005, 146:692-701.
24. Keegan A, Morecroft I, Smillie D, Hicks MN, MacLean MR: Contribution of the $5-\mathrm{HT}(1 \mathrm{~B})$ receptor to hypoxia-induced pulmonary hypertension: converging evidence using 5-HT(1B)-receptor knockout mice and the 5HT(1B/1D)-receptor antagonist GR127935. Circ Res 2001, 89:1231-1239.

25. MacLean MR, Sweeney G, Baird M, McCulloch KM, Houslay M, Morecroft I: 5 -Hydroxytryptamine receptors mediating vasoconstriction in pulmonary arteries from control and pulmonary hypertensive rats. $\mathrm{Br} J$ Pharmacol 1996, 119:917-930.

26. Sauvageau S, Thorin E, Villeneuve L, Dupuis J: Change in pharmacological effect of endothelin receptor antagonists in rats with pulmonary hypertension: role of ETB-receptor expression levels. Pulm Pharmacol Ther 2009, 22:311-317.

27. MacLean MR, McCulloch KM, Baird M: Endothelin ETA- and ETB-receptormediated vasoconstriction in rat pulmonary arteries and arterioles. J Cardiovasc Pharmacol 1994, 23:838-845.

28. Mam V, Tanbe AF, Vitali SH, Arons E, Christou HA, Khalil RA: Impaired vasoconstriction and nitric oxide-mediated relaxation in pulmonary arteries of hypoxia- and monocrotaline-induced pulmonary hypertensive rats. J Pharmacol Exp Ther 2010, 332:455-462.

29. Bonnet S, Dubuis E, Vandier C, Martin S, Marthan R, Savineau JP: Reversal of chronic hypoxia-induced alterations in pulmonary artery smooth muscle electromechanical coupling upon air breathing. Cardiovasc Res 2002, 53:1019-1028.

30. Hyvelin JM, Guibert C, Marthan R, Savineau JP: Cellular mechanisms and role of endothelin-1-induced calcium oscillations in pulmonary arterial myocytes. Am J Physiol 1998, 275:L269-282.

31. Ivy D, McMurtry IF, Yanagisawa M, Gariepy CE, Le Cras TD, Gebb SA, Morris KG, Wiseman RC, Abman SH: Endothelin B receptor deficiency potentiates ET-1 and hypoxic pulmonary vasoconstriction. Am J Physiol Lung Cell Mol Physiol 2001, 280:L1040-1048.

32. Guibert C, Marthan R, Savineau JP: 5-HT induces an arachidonic acidsensitive calcium influx in rat small intrapulmonary artery. Am J Physiol Lung Cell Mol Physiol 2004, 286:L1228-1236.

33. McDaniel SS, Platoshyn O, Wang J, Yu Y, Sweeney M, Krick S, Rubin LJ, Yuan JX: Capacitative $\mathrm{Ca}(2+)$ entry in agonist-induced pulmonary vasoconstriction. Am J Physiol Lung Cell Mol Physiol 2001, 280:L870-880.

34. Shimoda LA, Sylvester JT, Sham JS: Mobilization of intracellular $\mathrm{Ca}(2+)$ by endothelin-1 in rat intrapulmonary arterial smooth muscle cells. Am J Physiol Lung Cell Mol Physiol 2000, 278:L157-164.

35. Barman SA: Vasoconstrictor effect of endothelin-1 on hypertensive pulmonary arterial smooth muscle involves Rho-kinase and protein kinase C. Am J Physiol Lung Cell Mol Physiol 2007, 293:L472-479.

36. Rodat-Despoix L, Aires V, Ducret T, Marthan R, Savineau JP, Rousseau E, Guibert C: Signalling pathways involved in the contractile response to 5-HT in human pulmonary artery. Eur Respir J 2009, 34:1338-1347.

37. Sauzeau V, Le Jeune H, Cario-Toumaniantz C, Smolenski A, Lohmann SM, Bertoglio J, Chardin P, Pacaud P, Loirand G: Cyclic GMP-dependent protein kinase signaling pathway inhibits RhoA-induced Ca2+ sensitization of contraction in vascular smooth muscle. J Biol Chem 2000, 275:21722-21729.

38. de Wit C, Griffith TM: Connexins and gap junctions in the EDHF phenomenon and conducted vasomotor responses. Pflugers Arch 2010, 459:897-914.

doi:10.1186/1465-9921-12-30

Cite this article as: Billaud et al:: Role of the gap junctions in the contractile response to agonists in pulmonary artery from two rat models of pulmonary hypertension. Respiratory Research 2011 12:30. 